\title{
Exotic Mammal Record
}

\section{By R. W. Nero, Saskatchewan Museum of Natural History}

A small rodent which was killed in a warehouse in Yorkton on July 5 . 1959 , and which was submitted to the Museum by Dr. Stuart Houston, has been identified as a Central American cricetid rodent-Sumichrast's Vesper Rat (Nyctomys sumichrasti). The identification was made by Dr. C. O. Handley, Jr., U.S. National Museum, Washington, D.C., through the courtesy of Dr. F. Banfield, Naticnal Museum of Canada. The specimen was presumably carried in with a shipment of fruit. It is a male and lacks the end of the tail which is supposed to be tufted. In general appearance it looks something like a lcng-tailed hamsiter, being reddishbrown above and white beneath. According to Hall and Kelson (The Mammals of North America. 1959: 577) "the vesper rat is brightly colcred, arboreal, builds outside nests of twigs and fibres much like those of the red squirrel, and only occasicnally descends to the ground."

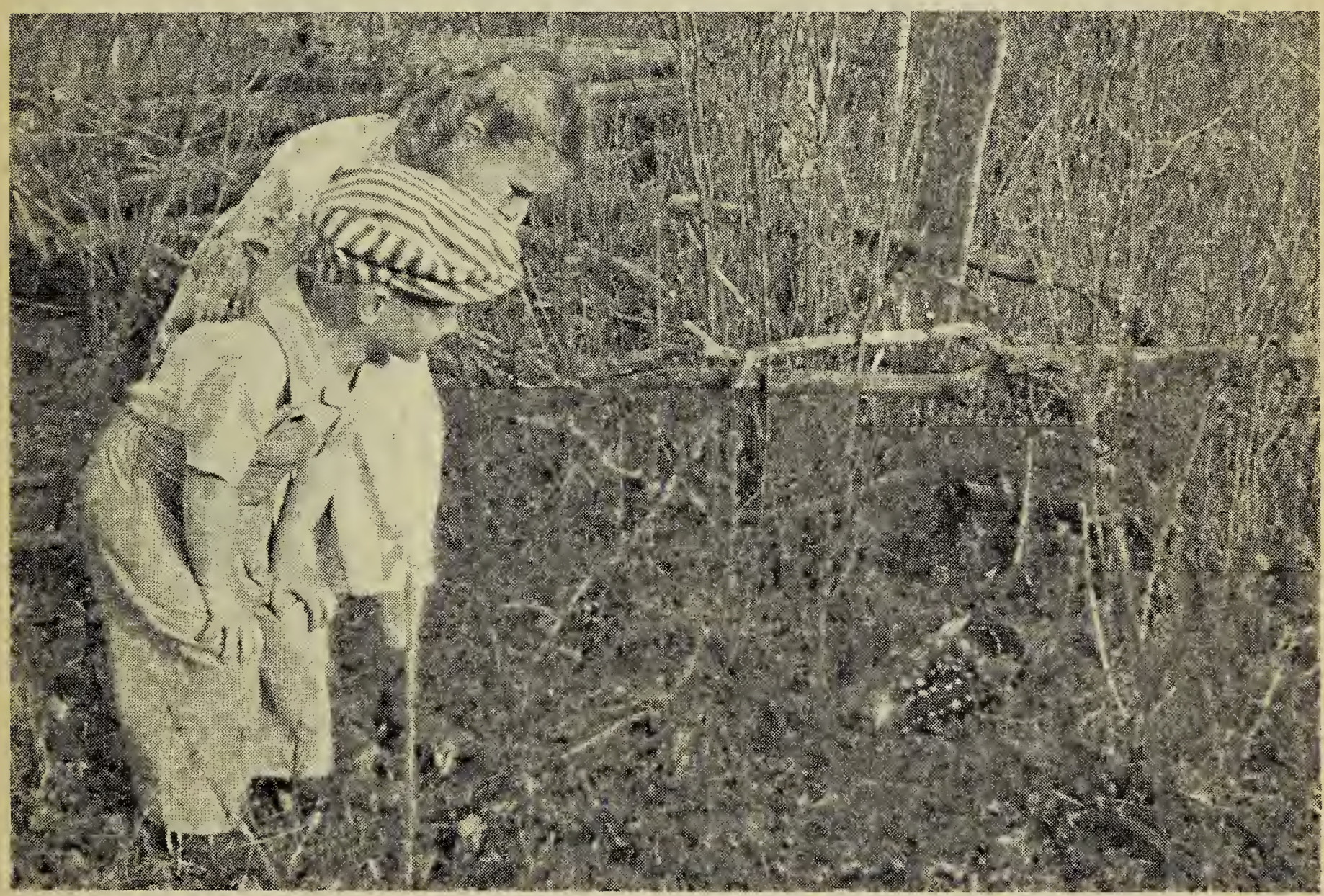

Photo by A. H. Hruska

Don't touch it! Patricia and Gordon Hruska with White-tailed Deer fawn, May, 1959.

\section{More About Painted Turtles}

By Arthur G. Kelly, Spy. Hill, Sask.

I live in the lower Qu'Appelle Valley about nine miles southwest of Spy Hill. I have seen some very large Painted Turtles around the mouth of Cut Arm Creek where it enters the Qu'Appelle River.

A few years ago I saw one of about eight inches in diameter that had just finished laying six eggs. The eggs were gelatine-like sacs or capsules about the size of pigeon eggs but not oval-shaped. Each end was the same. The turtle had climbed up a rather steep bank by the river that was exposed to the south. Then it dug a hole about six inches deep, laid its eggs and then packed the earth back quite tightly over them. I suppose the heat of the sun incubated the eggs and the steep bank helped the young turtles to reach the river. 